UDC 631.354.2:633.85

DOI: 10.31548/machenergy.2019.04.129-135

\title{
METHODOLOGY OF EXPERIMENTAL RESEARCH OF HYDROSEEDING PROCESS OF GEMITATED GRAIN
}

\author{
S. M. Deyneka, L. V. Aniskevich
}

National University of Life and Environmental Sciences of Ukraine. Ukraine.

Speciality of article: 133 - industry engineering.

Corresponding authors: deyneka5555@ukr.net.

Article history: Received:-August 2019, Accepted: November 2019.

Bible. 17, fig. 5, tabl. 2.

Abstract. The population of Ukraine is not provided with a sufficient number of vegetables. Insufficient amount of moisture in spring needs to improve the technology of vegetable crops sowing.

The work is devoted to the experimental study of the possibility to seed sprouted vegetable grain together with liquid. The article deals with the process of hydroseeding of germinated grain in which the most effective working parameters of the hydroseeder are realized. A new technological scheme for mixing of the seed mixture without traumatization of sprouters with the help of a mixing chamber of aerodynamic action is studied.

The proposed designs of hydroseeders and sowing machines due to their imperfections did not find implementation into production. The analysis of existing structures indicates that the degree of their introduction is the result of low evenness of seeding and high damaging of sprouts. The experimental research program includes determination of the even distribution of seeds in the mixing chamber in the conditions of various air pressures and water levels in the chamber, determination of the evenness of seeding depending on the number of seeds in the mixing chamber, determination the seed lifting speed depending on the size characteristics, determination of the optimal loss rate of the water and seed mixture in the hydroseeding process. The article deals with the materials of laboratory tests of the stationary experimental model of the hydroseeding apparatus. The research was conducted in the stationary mode with the use of modern equipment and methods of conducting scientific studies with the help of computer technologies. The purpose of experiments includes the definition of empirical coefficients that are determined by the test results. On the base of the conclusions on the article materials it is possible to develop of an optimal field research plan which can confirm the scientific hypothesis of the dependence of the evenness of seeding of germinated grain on the evenness of their distribution in the mixing chamber.

The interconnection of the structural and technological parameters of the seeding process of the hydromixture with the efficiency of the technological process is experimentally proved.

Key words: experiment, plan of the experiment, installation, factor randomization, empirical coefficients.

\section{Introduction}

The programme of experimental research includes determination of the even distribution of seeds in the mixing chamber in the conditions of various air pressures and water levels in the chamber, determination of the evenness of seeding which depends on the number of seeds in the mixing chamber, determination the seed lifting rate depending on the size characteristics, determination of the optimal flow rate of the water and seed mixture in the hydroseeding process.

\section{Formulation of problem}

Uninvestigated parts of general matters defining. Authors proposed a method of seeds placing into the soil and a device for its implementation, which transports the seeds to the coulter by a liquid flow under pressure from the hydraulic pump. The disadvantage of this process is inability to plant the germinated seeds.

\section{Analysis of recent research results}

The scientific researches [1-21] are devoted to the design of the hydroseeding apparatus, which would allow the seeding of germinated seeds with simultaneously irrigation in small doses of water.

Uninvestigated parts of general matters defining. V.F. Pashchenko and other authors proposed a method of seeds placing into the soil and a device for its implementation, which transports the seeds to the coulter by a liquid flow under pressure from the hydraulic pump. The disadvantage of this process is inability to plant the germinated seeds.

A well-known hydraulic seeding machine of such authors as M.F. Olkhovskyi and S.V. Halimonenko includes a tank with an agitator placed in it (the tank has an outlet which is equipped with a locking device installed in the distribution chamber), a control system that is installed in direct brackets with the possibility of vertical displacement of a spring loaded container. The disadvantages of these hydroseeder is an unstable regulatory effect on the pouring of water and seeds 
mixture. This sowing machine is unsatisfactory in open ground.

The patent search and the review of literary sources allowed revealing other models of hydroseeders. However, the proposed designs of hydroseeders and sowing machines due to their imperfections did not find implementation into production. The analysis of existing models indicates that the degree of their introduction is the result of low evenness of seeding and high damaging of sprouts.

\section{Purpose of research}

Purpose of the article is theoretical investigation of the hydroseeding process of fine vegetable germinated seeds.

\section{Results of research}

The experimental research program includes determination of the even distribution of seeds in the mixing chamber in the conditions of various air pressures $(\alpha)$ and water levels in the chamber $(\beta)$, determination of the evenness of seeding depending on the number of seeds in the mixing chamber, determination the seed lifting speed depending on the size characteristics, determination of the optimal loss rate of the water and seed mixture in the hydroseeding process.

To determine the even distribution of seeds in the volume of liquid under the action of air bubbles, we need to know their relative position with respect to each other.

The information on the theoretical and experimental determination of the distances between the seeds relative to the X, Y, Z axes and the effect on their values of the air pressure parameters and the liquid level in the chamber $(\alpha$ and $\beta$ ) was not found in special publications. For an analytical solution of the equation of kinematics of seeds in a liquid, we need to determine experimentally the nature of the movement of seeds in the liquid under the influence of air pressure, velocity, and the trajectory of their ascent.

To determine the trajectory and the ascending speed depending on the air pressure delivered through the perforated bottom of the chamber, we developed a laboratory-field unit that meets the following requirements:

1. The unit is provided with pressure control and the control of the size of the holes in the perforated bottom of the mixing chamber (the size of the holes $\mathrm{A}$ in the range 1-2 $\mathrm{mm}$ and the air pressure $\mathrm{B}$ in the range 0.1-0.6 atm.).

2. In the course of the experiment it is provided:

- the measurement of seed ascending speed (measurement error is $0.1 \mathrm{~s}$ ),

- the measurement of the density of the liquid,

- the measurement of travelling speed $v_{n}$ unit,

- the measurement of the process of seed distribution in the volume of the liquid.

3. Registration of information is carried out using a laptop with software for further information processing.
To install various perforated discs and maintain air pressure, the design of the unit has been constructed, providing the necessary range of factors $\mathrm{A}$ and $\mathrm{B}$ (Fig. 1).

To measure the lifting speed of seeds a measurable bulb with photodetectors was made. The photodetectors record the time of seeds lifting in the range of $0,8-20 \mathrm{~Hz}$ to within $5 \%$.

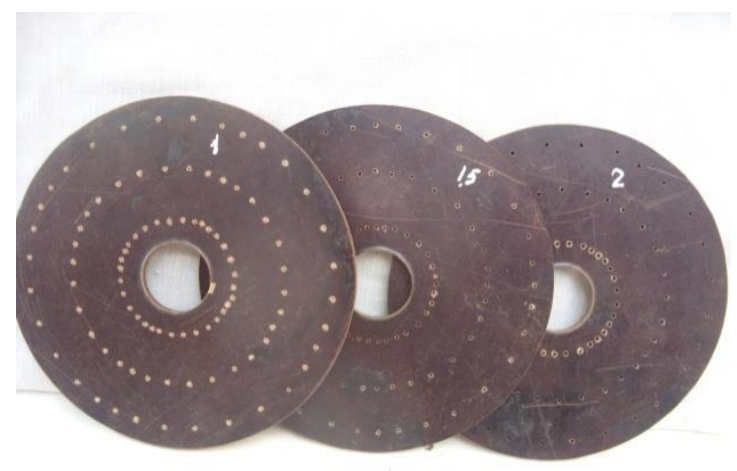

$a$

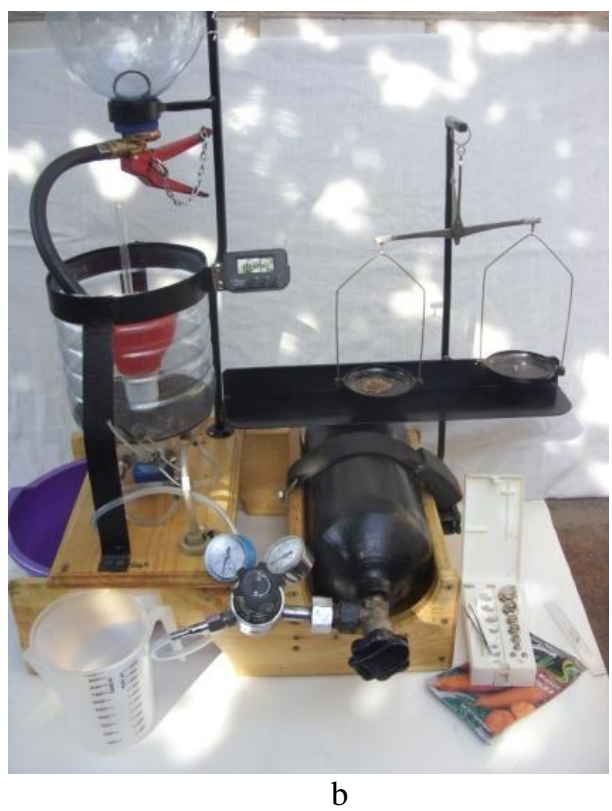

Fig. 1. The design concept of the unit a - the replacement of perforated discs of the bottom of the mixing chamber $b$ - the regularity of the air pressure $\beta$.

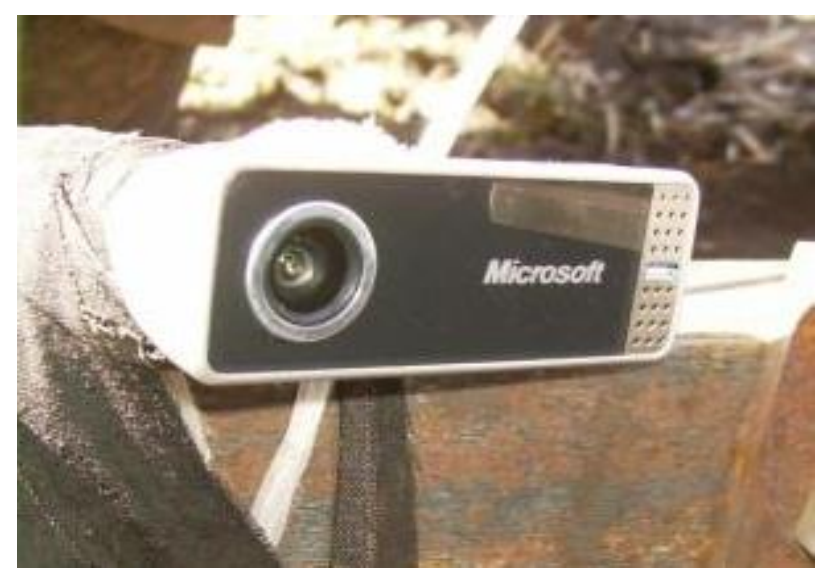

Fig. 2. Installation of WEB-cameras. 
For a visual observation of the process of interaction of seeds with air bubbles on a frame, the Microsoft Life Cam VX-70 webcam is rigidly mounted (Fig. 2)

All information from the sensors is translated into a digital code using the digital amplifier and converter Spider 8, then recorded and stored in the memory of the Omnibook-600 laptop computer (Fig. 3).

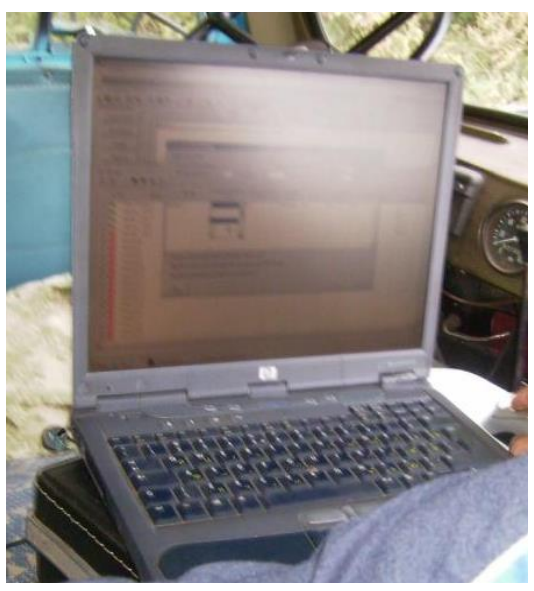

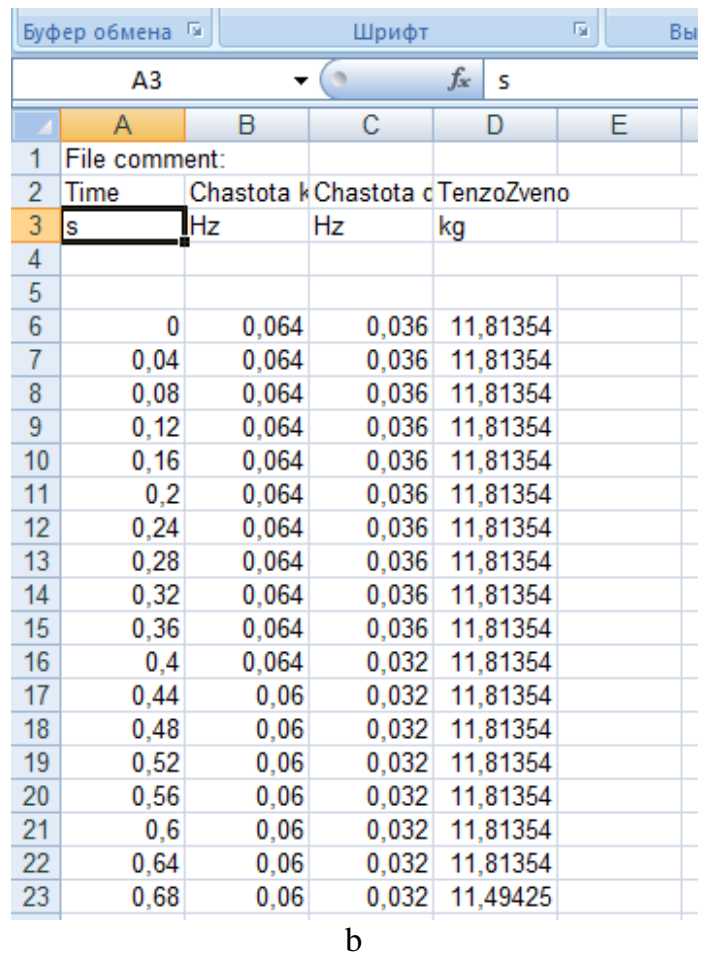

Fig. 3. Conducting a field experiment: a - measuring complex, $\mathrm{b}$ - registration of information on a laptop.

In column $A$ the time of seeds lifting is fixed, in column $B$ the bubble separation frequency is fixed, in column $C$ the frequency of operation of the photodetector is fixed, and in column $D$ the value of height of the liquid column above the seed catcher is fixed. The data is recorded with a frequency of 25 data per second. Further data processing is done using Statistica 6.0 software.

The methodology of experimental studies to determine the even distribution of seeds in the seedbed depends on the diameter of the seed catcher $\alpha$ and the height of the water and seed mixture over the level of the funnel $\beta$.
The experimental research is based on the methodology of the multifactorial experiment.

To organize and conduct multifactorial experiments it is necessary to perform the following stages of work: preliminary study of the research object, choice of factors and plan of experiments, factors coding, developing a matrix for planning experiments, randomization of experimental studies, conducting experiments, analysis and processing of the results, determination of regression coefficients, estimation of significant regression coefficients, constructing of a polynomial model and checking it for adequacy [7].

Preliminary evaluation of available research results and analysis of the process of interaction of air bubbles with seeds in a liquid medium allow to advance the hypothesis that the even distribution of seeds above the level of the funnel is nonlinear functions of air pressure $\alpha$, the diameter of the openings of the perforated chamber bottom of the mixer $\beta$ discs, as well as the level of the mixture over the catcher. At the first solving of the problem, a three-factor experiment is wanted. But the research experiments under field conditions made us certain that it was impossible to fix a "progressive speed" at a given level. The large speed range on the histogram practically covers the entire range of possible level variations from 0.5 to $1.5 \mathrm{~m} / \mathrm{s}$ (Fig. 4).

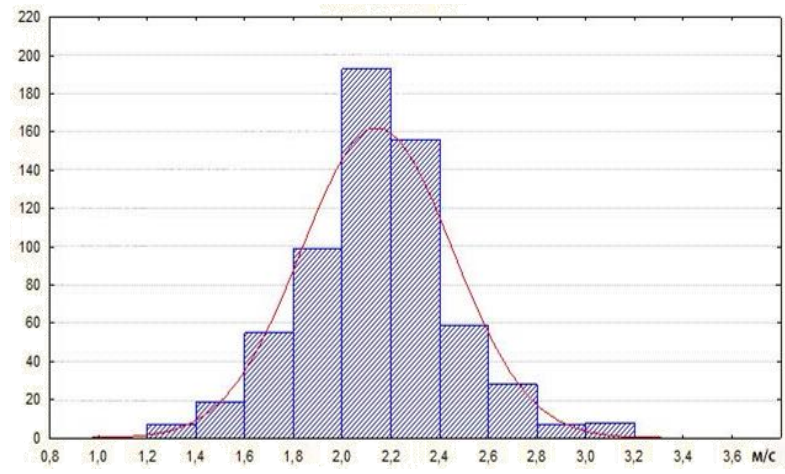

a

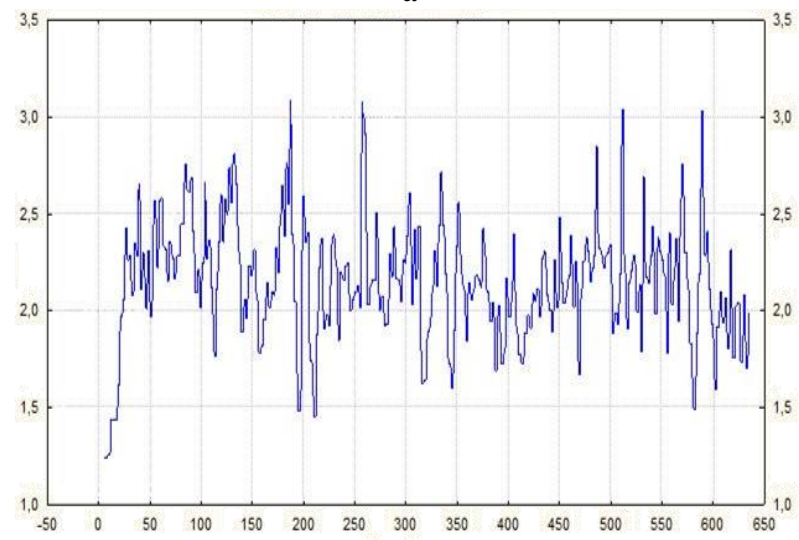

Fig. 4. Diagram of the unit speed measurements in time (a) and histogram of the unit speed (b)

The nature of the autocorrelation function and the spectral plane (Fig. 4) proved that under field conditions the unit speed can act as a controllable factor in multifactorial experiments (Fig. 5).

Thus, this raises the challenge to conduct a two-factor experiment of the second order. New studies on the theory 
of a multifactorial experiment show that used in practice orthogonal central composite plans (OCCP) and other plans for constructing of polynomial models of the second order are redundant in both the number of experimental points and the number of levels of factors variation.

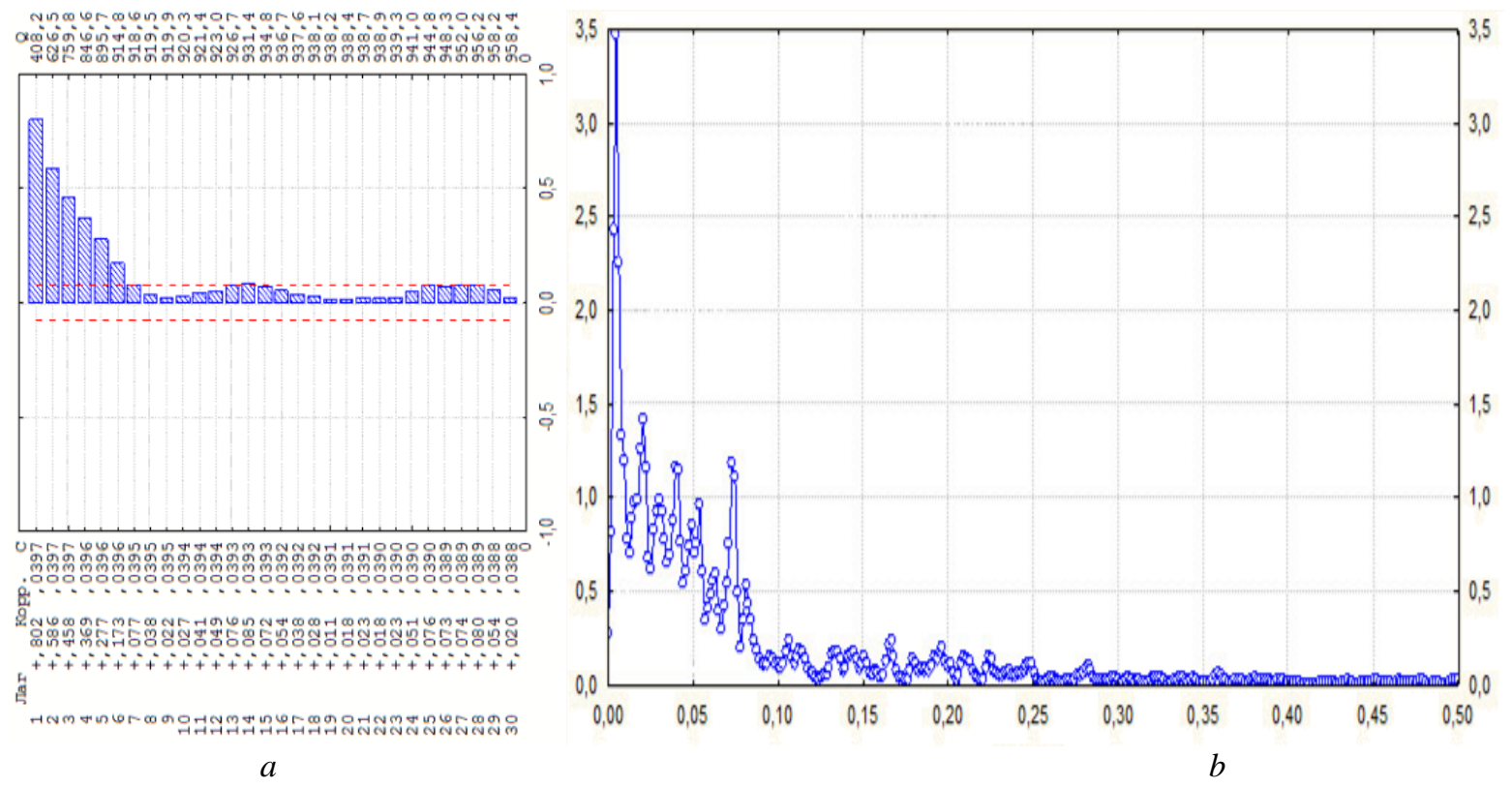

Fig. 5. Correlation function (a) and spectral density of the unit (b)

For example, for four factors the number of experimental points in the OCCP is 25 , and the number of unknown coefficients in the complete model of the second order is 15 . Therefore, to check the adequacy of the model there are 10 degrees of freedom.

For a number of factors greater than or equal to three, the number of levels of variation in the OCCP is five, at the same time, for the construction of the models of the second order three levels of variation of factors are enough. Hence, the OCCP is redundant both in the number of experimental points, and in the number of levels of factors variation.

The number of experimental points in the matrix of the OCCP is calculated by the formula:

$$
N=2^{n}+2 n+1
$$

where $N$ is the number of experimental points, $n$ is the number of factors.

The process model in the two-factor experiment of the second order is in the following form:

$$
y=b_{0}+b_{1} x_{1}+b_{2} x_{2}+b_{11} x_{1}^{2}+b_{22} x_{2}^{2}+b_{12} x_{1} x_{2}
$$

where $y$ is the investigated factor, $x_{1}$ and $x_{2}$ - variable factors, $b_{0}, b_{1}, b_{2}, b_{11}, b_{22}, b_{12}$ - empirical coefficients that need to be determined by the results of a multivariate experiment.

There is a large variety of plans for two-factor experiments of the second order. They are almost equivalent as for reflection of the reality of the described processes, but differ in the scope of experimental work [4].

As an alternative, consider the three most common points of the plan:

1. The central composite rotatable plan of the second order for two factors.

For realization of this plan it is necessary to conduct 13 experiments, if necessary, to identify 6 unknowns.
Provision of parameters of the regulated factor at star points in values of +1.414 and -1.414 is sometimes very problematic.

2. Central noncomposite plan of the second order. For realization of this plan it is necessary to conduct ten variants of the experiment. It is very difficult to provide $x_{2}$ parameters at levels +0.866 and -0.866 .

3 . The two-factor orthogonal central composite plan (OCCP) of the second order has recently been used in engineering practice due to a number of advantages over other plans. The feature of the task is that the object of the study is not the process itself, but statistical indicators that characterize this process in a steady state. In this case, the initial value is determined almost without error (due to a large number of measurements), and the result of each experiment is accurately reproduced in its repetition, if there are no random emissions.

Hence, there is no need to check the uniformity of sampling variances of reproducibility, in the conduct of randomization and duplication of experiments. At the same time, it is difficult to assess the significance of the coefficients and to check the adequacy of the mathematical model in the form of a polynomial.

The verification of the adequacy of approximating expressions on F-criteria and the significance of the coefficients on t-criteria in this case is inappropriate, since the sampling variance of reproducibility in determining the values of $y$ according to the graph is practically zero. At the same time, all the coefficients, even slightly different from zero, will be significant, and any deviations of the calculated by polynomial value $y$ from the values $\tilde{y}$ (taken from the characteristic) formally make the model inadequate. A similar problem of adequacy and significance of coefficients arises also when studying the mathematical model of an object on a computer.

In this case, the following ways are acceptable: consider all the coefficients significant, since the variance 
of experiments is practically absent (due to its lower significance), the estimation should be made on the basis of the accepted level of approximation accuracy, which is connected with the artificial introduction of the variance of reproducibility. Taking the value of the error of experiment for the initial parameter, the verification of the model adequacy can be made according to the F-criterion.

However, the correspondence of the approximating polynomial of an approximating curve or their family can be determined by the maximum absolute deviation of the values of the initial parameter calculated by polynomial from the values determined by the statistical characteristic.

The last way inferior to the mathematical rigor of the first two. However, considering the graphic description of the statistical properties of the object, this way is quite acceptable under the approximation of statistical characteristics [1].

The special features of experimental methods for mathematical representation of statistical characteristics include the fact that in this case the experiment (defining initial parameter values using the diagram) does not require a lot of time and resources. The experiment is not expensive. Therefore, the question of minimizing of the number of necessary experiments is not as acute as when planning an industrial experiment. In the general case, there is no need for the consistent nature of the experiment, since the character of the statistical characteristics is already known. For example, if the statistical characteristic shows that the connection $y=f\left(x_{1} x_{2}\right)$ is non-linear, then, as a rule, there is no need to use more simple models [5].

Because of some difficulty of estimating the adequacy of the model, it seems appropriate to use nonlinear plans even in the cases where the nonlinearity of statistical characteristics is hardly noticeable. The degree of nonlinearity can be inferred by the value of the coefficients under the quadratic terms of the polynomial. Nonlinear plans are more versatile.

Enter the next range of air pressures and the levels of the mixture over the seed catcher:

$$
\begin{aligned}
& \alpha_{\min }=1 \text { aTM., } \alpha_{\max }=6 \text { атм., } \beta_{\min }=1 \mathrm{MM}, \\
& \beta_{\max }=5 \text { мм. }
\end{aligned}
$$

For multi-factorial experiment the second-order OCC-plan for two factors is used. It is presented in the table 1 .

Table 1. OCC - plan of the second order for two factors.

\begin{tabular}{|c|c|c|}
\hline Number of Experiments & $x_{1}$ & $x_{2}$ \\
\hline 1 & -1 & -1 \\
\hline 2 & -1 & +1 \\
\hline 3 & +1 & +1 \\
\hline 4 & +1 & -1 \\
\hline 5 & +1 & 0 \\
\hline 6 & -1 & 0 \\
\hline 7 & 0 & +1 \\
\hline 8 & 0 & -1 \\
\hline 9 & 0 & 0 \\
\hline
\end{tabular}

Factors vary in the next range (table 2).

Thus, the features of this plan are 1) the smallest number of variants of research experiments from the existing (9 variants), 2) there are only three factors, which are studied and the results of the experiments are rounded up to a whole number $(+1,0,-1), 3)$ particularity of imagination of a priori information.

Table 2. Factors in the natural size.

\begin{tabular}{|c|l|l|}
\hline \multirow{3}{*}{$x_{1 .}=\alpha$} & $x_{1}=0,5 \mathrm{MM}$ & -1 \\
\cline { 2 - 3 } & $x_{1}=1 \mathrm{MM}$ & 0 \\
\cline { 2 - 3 } & $x_{1}=1,5 \mathrm{MM}$ & +1 \\
\hline \multirow{3}{*}{$x_{2}=\beta$} & $x_{2}=0,1 \mathrm{aTM}$. & -1 \\
\cline { 2 - 3 } & $x_{2}=0,3 \mathrm{aTM}$. & 0 \\
\cline { 2 - 3 } & $x_{2}=0,6 \mathrm{aTM}$. & +1 \\
\hline
\end{tabular}

\section{Conclusions}

1. The scientific fundamentals of principles of action and design of a hydroseeder for seeding of fine vegetable germinated seeds are examined.

2. The mathematical models of some processes are proposed. The using of them allows dividing the general process of designing the hydrseeding apparatus into the following phases:

-the process of bubbling,

-the process of mixing seeds in a liquid,

-the process of water and seed mixture pouring.

3. The application of a set of physical processes makes it possible to achieve the high quality of the process of hydroseeding of sprouted seeds without traumatization of sprouters

4. The conducted theoretical studies of the hydroseeding process give the opportunity to form the main directions of experimental researches of both individual processes and the general process. Optimization of operating modes of these processes allows solving the question of the hydroseeder design. Thus, it is possible to shorten the period of having harvest of vegetable crops by reducing the period of sprouts emergence.

\section{References}

1. Nedovyesov, V. I., Loveikin, V. S., Bondar, N. A., Shimko, L. S. (2009). Patent 87400 Ukraine, IPC A01D $41 / 00$. Combine harvester, the applicant and owner of the national scientific center "Institute of mechanization and electrification of agriculture" UAAS. № a 200800537 , Appl. 15.01.2008, publ. 25.04.2008, bull. No. 8.

2. Nedovyesov, V. I., Loveikin, V. S., Bondar, N. A., Shimko, L. S. (2009). 44046 Patent, Ukraine, IPC A01F 12/60. The hopper combine harvester, the applicant and owner of NULESU. - № u 200905 304, Appl. 27.05.2009, publ. 10.09.2009, bull. No. 17 .

3. Nedovyesov, V. I., Loveikin, V. S., Bondar, N. A., Shimko, L. S. (2009). 49301 Patent, Ukraine, IPC 01D $41 / 00$. Combine harvester, the applicant and the owner of NULESU. № u 200911 175, Appl. 04.11.2009, publ. 26.04.2010, bull. No. 8 . 
4. Nedovyesov, V. I., Loveikin, V. S., Bondar, N. A., Shimko, L. S. (2009). 51244 Patent, Ukraine, IPC A01F $12 / 60$. The hopper combine harvester, the applicant and owner of NULESU. - № u 2009 13874, Appl. 29.12.2009, publ. 12.07.2010, bull. No. 13 .

5. Takahasi, K. (1937). The Gravity flow in nature. Geophys. Mag. Vol. 11. 165-175.

6. Roberts, A. (1969). Study the expiry is a bulk granular material through the discharge chute under its own weight. Proceedings of the American society of mechanical engineers. Design and manufacturing engineering. Vol. 9, Series V. No. 2. 87-96.

7. Roberts, A. W. (1960). Trans. ASME, J. Engng. Ind., 91. 373-381.

8. Ishida, M., Shirai, T. (1979). Velocity Distributions in the Flow of Particles in an Inclined Open Channel. J. Chem. Eng. Jpn. Vol. 12. 45-50.

9. Savage, S. B., Sayed, M. (1980). Experiments on dry cohesion less materials in annular cell at high stain rates.-Presented at EUROMECH 133-Statics and Dynamics of Granular Materials, Oxford University.

10. Savage, S. B. (1987). Interparticle percolation and segregation in granular materials: A review. In A. P. S. Selvaduraj (ed) Development in Engineering Mechanisms, Elsevier Science Publishers B. V., Amsterdam. 347-363.

11. Dolgunin, V. N. (2005). Rapid gravity flow of granular materials: technique of measurement, the patterns used in technological applications. Moscow. Mechanical engineering. 112.

12. Borschev, V. J. (2002). Computer processing of radiographs in the study of the dynamics of rapid gravity flows of granular media. Mathematical methods in technics and technology: collected papers. Tambov, Vol. 7. 34-37.

13. Kulikovsky, V. L., Paliychuk, V. K., Borovsky, V. M. (2017). Injury of the grain material of screw working bodies of screw feeders. Design, production and operation of agricultural machinery. Kropiwnicki. CSTS. Vol. 47, C. I. 124-131.

14. Derevyanko, D. A. (2014). Injury and seed quality at different stages of technological processes. Engineering nature. No. 1(1). 114-123.

15. Kirpa, N. J. (2013). Injury of seeds: causes and consequences. Storage and processing of grain. Vol. 2 (167). 29-31.

16. Loveikin, V. S., Shimko, L. S. (2011). Experimental study of the process of discharging grain materials from a dump hopper of the combine. Scientific reports Nulesu. Kiev. Vol. 6(28): http://nd.nubip.edu.ua/2011_6/titul.html.

17. Loveikin, V. S., Shimko, L. S. (2015). Optimization of operation modes of dump eventaually devices. Kiev. 292.

\section{Список літератури}

1.Нєдовєсов В. І., Ловейкін В. С., Бондар М. А., Шимко Л. С. Патент 87400 Україна, МПК (2009) A01D 41/00. Зернозбиральний комбайн; заявник та власник Національний науковий центр «Інститут механізації та електрифікації сільського господарства» УААН. - № а 200800 537; заявл. 15.01.2008; опубл. 25.04.2008, бюл. № 8 .

2.Нєдовєсов В. І., Ловейкін В. С., Матухно Н. В., Шимко Л. С. Патент 44046 Україна, МПК (2009) А01F 12/60. Бункер зернозбирального комбайна; заявник та власник НУБІП України. - № u 200905 304; заявл. 27.05.2009; опубл. 10.09.2009, бюл. № 17

3.Нєдовєсов В. I., Ловейкін В. С., Матухно Н. В., Шимко Л. С. Патент 49301 Україна, МПК (2009) A01D 41/00. Зернозбиральний комбайн; заявник та власник НУБІП України. - № u 200911 175; заявл. 04.11.2009; опубл. 26.04.2010, бюл. № 8 .

4.Нєдовєсов В. I., Ловейкін В. С., Матухно Н. В., Шимко Л. С. Патент 51244 Україна, МПК (2009) А01F $12 / 60$. Бункер зернозбирального комбайна; заявник та власник НУБІП України. - № u 2009 13874; заявл. 29.12.2009; опубл. 12.07.2010, бюл. № 13.

5.Takahasi K. The Gravity flow in nature. Geophys. Mag. 1937. Vol. 11. P. 165-175.

6.Робертс $A$. Исследование истечения идеально сыпучего зернистого материала через разгрузочные желоба под действием собственного веса. Труды американского общества инженеров-механиков. Конструирование и технология машиностроения. 1969. Т. 9, Серия В. №2. С. 87-96.

7. Roberts A. W. Trans. ASME, J. Engng. Ind., 1960, 91. P. 373-381.

8.Ishida M., Shirai T. Velocity Distributions in the Flow of Particles in an Inclined Open Channel. J. Chem. Eng. Jpn. 1979. Vol. 12. P. 45-50.

9.Savage S. B., Sayed M. Experiments on dry cohesion less materials in annular cell at high stain rates.Presented at EUROMECH 133-Statics and Dynamics of Granular Materials, 1980.-Oxford University.

10. Savage $S$. B. Interparticle percolation and segregation in granular materials: A review. In A.P.S. Selvaduraj (ed) Development in Engineering Mechanisms, Elsevier Science Publishers B.V., Amsterdam, 1987. P. 347-363.

11. Долгунин B. H. Быстрые гравитационные течения зернистых материалов: техника измерения, закономерности, технологическое применение. Москва. Машиностроение, 2005. 112 с.

12. Борщев $B . \quad$ Я. Компьютерная обработка рентгенограмм при исследовании динамики быстрых гравитационных течений зернистых сред. Математические методы в технике и технологиях: Сборник трудов. Тамбов, 2002. Т. 7. С. 34-37.

13. Куликівський В. Л., Палійчук $\quad$ B. $\quad$ K., Боровський В. М. Травмування зернового матеріалу гвинтовими робочими органами шнекових живильників. Конструювання, виробництво та експлуатація сільськогосподарських машин. Кропивницький. ЦНТУ, 2017. Вип. 47, ч. І. С. 124131.

14. Дерев'янко Д. А. Травмування та якість насіння на різних стадіях технологічних процесів. Інженерія природокористування. 2014. №1(1). С. 114 123.

15. Кирпа Н. Я. Травмирование семян: причины и следствия. Хранение и переработка зерна. 2013. Вип. №2 (167). С. 29-31. 
16. Ловейкін В. С., Шимко Л. С. Експериментальні дослідження процесу вивантаження зернових матеріалів із самоскидного бункера комбайна. Наукові доповіді НУБіП України. Київ. Вип. 6(28): http://nd.nubip.edu.ua/2011_6/titul.html.

17. Ловейкін В. С., Шимко Л. С. Оптимізація режимів роботи самоскидних вивантажувальних пристроїв. Київ. 2015. 292 с.

\section{МЕТОДИКА ЕКСПЕРИМЕНТАЛЬНИХ ДОСЛІДЖЕНЬ ГІДРОПОСІВУ ПРОРОЗШОГО НАСІННЯ \\ С. М. Дейнека, Л. В. Аніскевич}

Анотація. Населення України не забезпечується достатньою кількістю овочів власного виробництва. Через недостатню кількість вологи навесні необхідно вдосконалювати технології посіву овочевих культур. Робота присвячена експериментальному дослідженню можливості посіву пророщених насіння овочевих культур разом з рідиною, обгрунтуванню процесу гідросівби пророщеного насіння, в якому реалізуються найбільш ефективні робочі параметри гидросеялки, дослідженню нової технологічної схеми перемішування посівної суміші без травмування паростків насіння за рахунок впровадження змішувальної камери аеродинамічного дії. Запропоновані конструкції гидросеялок і высевных апаратів 3-за їх неефективності не були масово впроваджені у виробництво. Аналіз існуючих конструкцій свідчить, що ступінь їх впровадження $\epsilon$ результатом низької рівномірності висіву і високого травмування паростків.

Програмою експериментальних досліджень передбачено: визначення рівномірності розподілу насіння у змішувальній камері при різних значеннях тиску повітря і рівнях рідини в камері, визначення рівномірності загортання насіння в залежності від кількості насіння у змішувальній камері, визначення швидкості підйому насіння в залежності від розмірних характеристик, визначення оптимального використання водозмінної суміші в процесі гідропосіву. В статті представлені матеріали лабораторних досліджень стаціонарної експериментальної установки гідровисівного апарату. Дослідження проводились у стаціонарному режимі 3 використанням сучасного обладнання i методик проведення наукових експериментів за допомогою комп'ютерних технологій. Мета експериментів включає визначення емпіричних коефіцієнтів, які визначаються по результатах досліджень. Висновки з матеріалів статті дають можливість розробити оптимальний план польових досліджень, які можуть підтвердити наукову гіпотезу залежності рівномірності висіву пророщених насіння від рівномірності їх розподілу в змішувальній камері.

Експериментально визначено взаємозв'язок конструктивних і технологічних параметрів процесу висіву гідросуміші 3 ефективністю виконання технологічного процесу.

Ключові слова: експеримент, план експерименту, установка, рандомізація факторів, емпіричні коефіцієнти.

\section{МЕТОДИКА ЭКСПЕРИМЕНТАЛЬНЫХ ИССЛЕДОВАНИЙ ГИДРОПОСЕВА ПРОРОЩЕНЫХ СЕМЯН \\ С. Н. Дейнека, Л. В. Анискевич}

Аннотация. Население Украины не обеспечивается достаточным количеством овощей собственного производства. Из-за недостаточного количество влаги весной необходимо совершенствовать технологии посева овощных культур. Работа посвящена экспериментальному исследованию возможности посева пророщенных семян овощных культур вместе с жидкостью, обоснованию процесса гидропосева пророщенных семян, в котором реализуются наиболее эффективные рабочие параметры гидросеялки, исследованию новой технологической схемы перемешивания посевной смеси без травмирования ростков семян за счет внедрения смесительной камеры аэродинамического действия. Предложенные конструкции гидросеялок и высевных аппаратов из-за их неэффективности не были массово внедрены в производство. Анализ существующих конструкций свидетельствует, что степень их внедрения есть результатом низкой равномерности посева и высокого травмированию ростков.

Программой экспериментальных исследований предусмотрено: определение равномерности распределения семян в смесительной камере при разных значениях давления воздуха и уровнях жидкости в камере, определение равномерности посева семян в зависимости от количества семян в смесительной камере, определение скорости подъёма семян в зависимости от размерных характеристик, определение оптимального использования водосеменной смеси в процессе гидропосева. В статье представлены материалы лабораторных исследований стационарной экспериментальной установки гидровысевного аппарата. Исследования проводились в стационарном режиме с использованием современного оборудования и методик проведения научных экспериментов с помощью компьютерных технологий. Цель экспериментов включает определение эмпирических коэффициентов, определяющихся по результатах исследований. Выводы из материалов статьи дают возможность разработать оптимальный план полевых исследований, которые могут подтвердить научную гипотезу зависимости равномерности посева пророщенных семян от равномерности их распределения в смесительной камере.

Экспериментально определена взаимосвязь конструктивных и технологических параметров процесса высева гидросмеси с эффективностью исполнения технологического процесса.

Ключевые слова: эксперимент, план эксперимента, установка, рандомизация факторов, эмпирические коэффициенты.

S. M. Deyneka ORCID 0000-0003-1015-2457.

L. V. Aniskevich ORCID 0000-0002-4429-2020. 
